U. S. Department of Energy Hydrogen Program

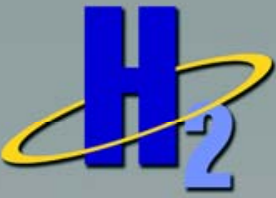

\title{
Go/No-Go Recommendation for Sodium Borohydride for On-Board Vehicular Hydrogen Storage
}

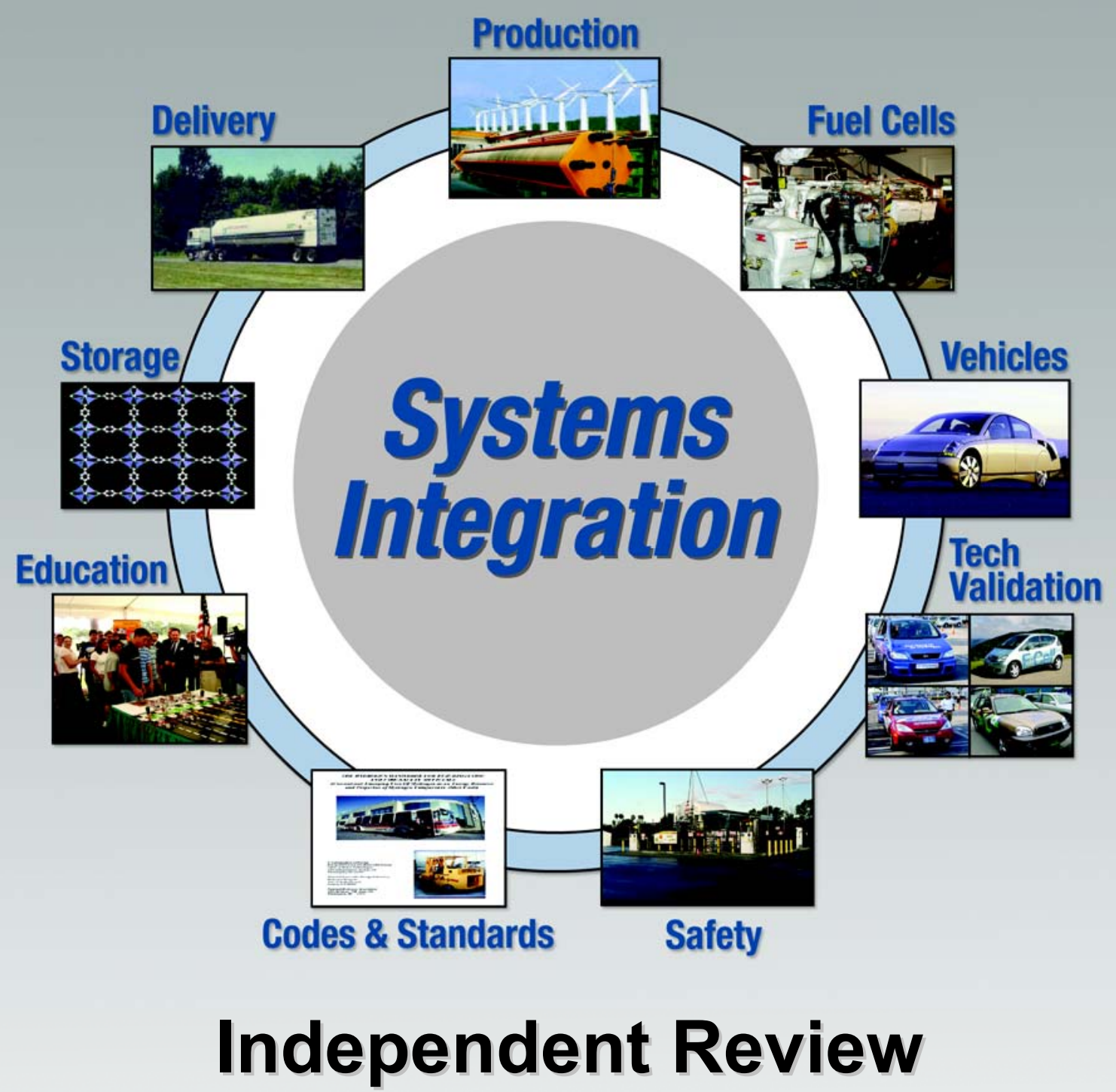

November 2007

National Renewable Energy Laboratory

1617 Cole Boulevard Golden, Colorado 80401-3393

303-275-3000 • www.nrel.gov

NREL is a U. S. Department of Energy Laboratory operated by Midwest Research Institute and Battelle

Contract No. DE-AC36-98-G010337 


\section{NOTICE}

This report was prepared as an account of work sponsored by an agency of the United States government. Neither the United States government nor any agency thereof, nor any of their employees, makes any warranty, express or implied, or assumes any legal liability or responsibility for the accuracy, completeness, or usefulness of any information, apparatus, product, or process disclosed, or represents that its use would not infringe privately owned rights. Reference herein to any specific commercial product, process, or service by trade name, trademark, manufacturer, or otherwise does not necessarily constitute or imply its endorsement, recommendation, or favoring by the United States government or any agency thereof. The views and opinions of authors expressed herein do not necessarily state or reflect those of the United States government or any agency thereof.

\footnotetext{
Printed on paper containing at least $50 \%$ wastepaper, including $20 \%$ postconsumer waste
} 


\section{INDEPENDENT REVIEW PANEL RECOMMENDATION REPORT}

November 30, 2007

From: Independent Review Panel, Go/No-Go Recommendation for Hydrolysis of Sodium Borohydride for OnBoard Vehicular Hydrogen Storage

\section{Subject: $\quad$ Go/No-Go Recommendation Report}

Per the evaluation criteria of the Independent Review Panel's charter for the subject decision, the Panel's unanimous technical recommendation follows. The Panel arrived at this recommendation after (1) reviewing technical briefings from DOE's contractors, (2) considering input from the FreedomCAR and Fuel Partnership's Hydrogen Storage Tech Team, and (3) deliberating the issues over five months (May-September 2007).

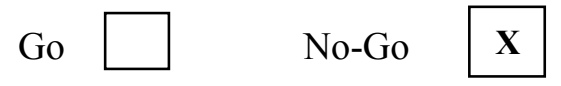

\section{Recommendation Statement}

The hydrogen storage technology considered for the hydrolysis of sodium borohydride $\left(\mathrm{NaBH}_{4}\right)$ has clearly not met all the 2007 targets. In addition, the Panel sees no promising path forward for this technology to reach all the 2010 targets. Based on its charter, then, the Panel unanimously recommends a No-Go decision.

\section{Rationale for Recommendation}

The rationale for the No-Go recommendation was based on whether the 2007 targets were met, coupled with the likelihood that 2010 targets could be met. Each of these targets is outlined in the table that follows ${ }^{1}$. (See Appendix A for evaluation criteria.)

\begin{tabular}{|c|c|c|c|}
\hline \multicolumn{4}{|c|}{ Selected DOE Hydrogen Storage Technical Targets } \\
\hline \multirow[t]{2}{*}{ Storage Parameter } & \multirow[t]{2}{*}{ Units } & \multicolumn{2}{|c|}{ Year } \\
\hline & & 2007 & 2010 \\
\hline $\begin{array}{l}\text { System gravimetric capacity: Usable specific } \\
\text { energy from } \mathrm{H}_{2} \text { (net useful energy/max system } \\
\text { mass) }\end{array}$ & $\begin{array}{l}\text { kWh/kg } \\
\text { (kg H} / 2 / k g \text { system) }\end{array}$ & $\begin{array}{c}1.5 \\
(0.045)\end{array}$ & $\begin{array}{c}2 \\
(0.06)\end{array}$ \\
\hline $\begin{array}{l}\text { System volumetric capacity: } \\
\text { Usable energy density from } \mathrm{H}_{2} \text { (net useful } \\
\text { energy/max system volume) }\end{array}$ & $\begin{array}{l}\text { kWh/L } \\
\text { (kg H} H_{2} / \text { L system) }\end{array}$ & $\begin{array}{c}1.2 \\
(0.036)\end{array}$ & $\begin{array}{c}1.5 \\
(0.045)\end{array}$ \\
\hline $\begin{array}{l}\text { Storage system cost } \\
\text { (and hydrogen cost) }\end{array}$ & $\begin{array}{l}\text { \$/kWh net } \\
\left(\$ / \mathrm{kg} \mathrm{H}_{2}\right) \\
\$ / \mathrm{gge} \text { at pump }\end{array}$ & $\begin{array}{c}6 \\
(200) \\
-\end{array}$ & $\begin{array}{c}4 \\
(133) \\
2-3\end{array}$ \\
\hline
\end{tabular}

1 For a complete list of DOE's hydrogen storage technical targets, see the hydrogen storage section of DOE's Hydrogen, Fuel Cells \& Infrastructure Technologies Program's Multi-Year RD\&D Plan: http://www1.eere.energy.gov/hydrogenandfuelcells/mypp/pdfs/storage.pdf 
The source of information and basis for the panel's decision are elaborated on in supporting documentation provided by the Panel. In addition to the technical targets listed in the table, the Panel recognized that hydrogen storage systems must be energy efficient in delivering hydrogen to the vehicle power plant. For on-board reversible systems, greater than $90 \%$ energy efficiency for the energy delivered to the power plant from the onboard storage system is required. For systems regenerated off board, the overall efficiency is important. In this case, the energy content of the hydrogen delivered to the automotive power plant should be greater than $60 \%$ of the total energy input to the process, including the input energy of hydrogen and any other fuel streams for generating process heat and electrical energy.

In terms of gravimetric and volumetric capacities, calculated system numbers were reported that, in some cases, meet the 2007 targets. These numbers, however, were estimates based on overly optimistic/untenable system concepts and were not truly complete system capacities. More realistic assumptions, including net releasable hydrogen, lead to capacity numbers below the 2007 targets. Measured system capacity numbers for actual, constructed systems (based on a previous design) are well below the 2007 targeted values. For both volumetric and gravimetric capacities, there is no clear pathway for solution-based hydrolysis of $\mathrm{NaBH}_{4}$ to achieve the 2010 targets. The most significant concerns about the system-level capacities involve: 1) the untested single-tank (fuel/spent fuel) bladder system, and 2) the solid-state precipitation of spent fuel (associated with reaction of concentrated $\mathrm{NaBH}_{4}$ solutions).

The analysis of system cost indicates that the 2007 system cost target might be achievable using the proposed systems and designs. However, the "net system" cost will be higher because of additional energy requirements.

In terms of hydrogen cost and energy efficiency, the Panel found the high energy penalty and cost of regenerating sodium borate $\left(\mathrm{NaBO}_{2}\right)$ back to $\mathrm{NaBH}_{4}$ fuel to be of significant concern. Although substantial progress was made in this area and innovative ideas were demonstrated, the 2010 hydrogen cost target does not appear within reach. In addition, many of the novel processing pathways involve using substantial amounts of electricity, and only with optimistic assumptions about the cost of electricity can efficiencies come close to the DOE goal. Assuming the projected grid mix in 2015, the regeneration strategies do not reach the efficiency goal.

There is no question that the reported cost and efficiency results for regeneration reported by both Millennium Cell and Rohm and Haas fall short of the DOE goals. The 2007 goals have not been achieved, making the prospect of achieving the 2010 and 2015 goals highly speculative. And even though the chemistry has shown much progress in the direction of meeting those goals, the prospects for going to the next level in meeting performance objectives are not promising. The Panel acknowledges that breakthrough advances in preparative chemistry are not easy, especially when dealing with methodology that has been in place for more than 50 years. Based purely on the criteria set out by DOE, the Panel's evaluation led to a No-Go decision.

As a result, the Panel concludes that a No-Go is the only possible decision for the hydrolysis of $\mathrm{NaBH}_{4}$ on-board storage system, based on the charter defining its mission. In addition, the Panel recognizes that improvements in $\mathrm{NaBH}_{4}$ production have application to the cost-effective production of amine boranes, for the alternative boranebased on-board storage system, which is a major area of research under the DOE Chemical Hydrogen Storage Center of Excellence. Therefore, the Panel is recommending that some continued research activities related to the cost-effective production of amine boranes may be appropriate. This does not contradict the Panel's no-go recommendation for on-board sodium borohydride; the recommended future work relates to addressing the viability of chemical hydrogen storage approaches as an alternative to sodium borohydride. 


\section{Contents}

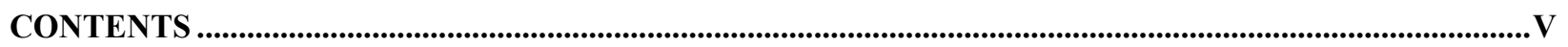

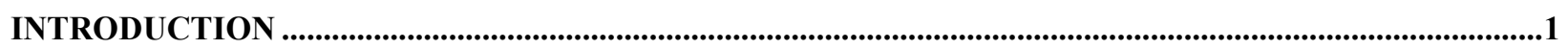

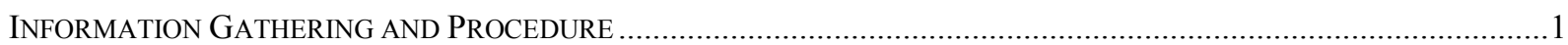

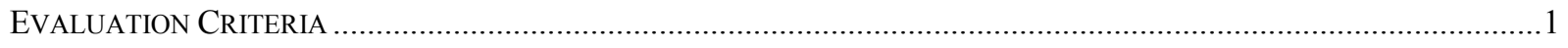

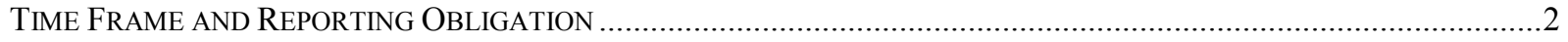

RECOMMENDATION AND CONCLUSIONS ...................................................................................2

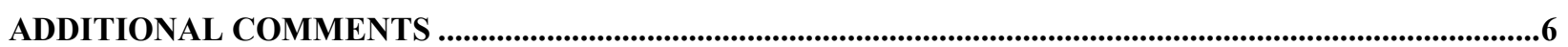

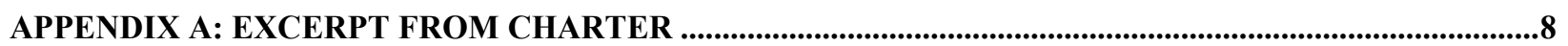

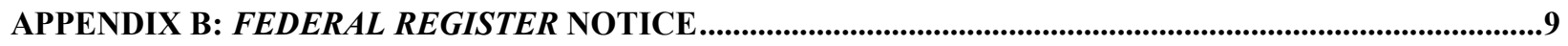

APPENDIX C: MATERIALS REVIEWED BY THE PANEL ..........................................................................12 


\section{Introduction}

The U.S. Department of Energy's (DOE) Hydrogen, Fuel Cells \& Infrastructure Technologies (HFCIT) Program commissioned the National Renewable Energy Laboratory (NREL) to identify and convene a qualified Independent Review Panel (referred to as the Panel from this point forward). The Panel's charter (see Appendix A) was to conduct a technical evaluation of the status and progress of R\&D in the area of hydrolysis of sodium borohydride $\left(\mathrm{NaBH}_{4}\right)$ for on-board vehicular hydrogen storage and its potential to meet DOE's time-phased technical targets and goal. DOE will consider this technical evaluation as it makes a Go/No-Go decision about continuing to fund R\&D in this area.

\section{Information Gathering and Procedure}

The primary sources of information for the Panel's independent assessment came from an in-depth review of the latest results of research conducted by DOE contractors in this area, as presented at a meeting at Argonne National Laboratory (ANL), held September 10-11, 2007. The Panel also considered the response to a 2006 Federal Register announcement (see Appendix B), along with DOE's HFCIT FY 2007 Annual Merit Review and Peer Evaluation ${ }^{2}$ presentations, white papers, quarterly reports, and other relevant technical documentation (see Appendix C). Finally, the Panel held conversations about the research with the FreedomCAR Hydrogen Storage Tech Team and other technical experts.

\section{Evaluation Criteria}

The Panel based its $\mathrm{NaBH}_{4}$ Go/No-Go recommendation primarily on an analysis of whether the 2007 technical targets given in Table 1 were met and the likelihood that the 2010 targets could be met.

Table 1. Selected DOE Hydrogen Storage Technical Targets ${ }^{3},{ }^{4}$

\begin{tabular}{|c|c|c|c|}
\hline \multirow[t]{2}{*}{ Storage Parameter } & \multirow[t]{2}{*}{ Units } & \multicolumn{2}{|c|}{ Year } \\
\hline & & 2007 & 2010 \\
\hline $\begin{array}{l}\text { System gravimetric capacity: Usable specific } \\
\text { energy from } \mathrm{H}_{2} \text { (net useful energy/max syst mass) }\end{array}$ & $\begin{array}{l}\mathrm{kWh} / \mathrm{kg} \\
\text { (kg H} / 2 / \mathrm{kg} \text { system) }\end{array}$ & $\begin{array}{c}1.5 \\
(0.045)\end{array}$ & $\begin{array}{c}2 \\
(0.06)\end{array}$ \\
\hline $\begin{array}{l}\text { System volumetric capacity: } \\
\text { Usable energy density from } \mathrm{H}_{2} \text { (net useful } \\
\text { energy/max system volume) }\end{array}$ & $\begin{array}{l}\mathrm{kWh} / \mathrm{L} \\
\text { (kg H} \mathrm{H}_{2} / \mathrm{L} \text { system) }\end{array}$ & $\begin{array}{c}1.2 \\
(0.036)\end{array}$ & $\begin{array}{c}1.5 \\
(0.045)\end{array}$ \\
\hline $\begin{array}{l}\text { Storage system cost } \\
\text { (and hydrogen cost) }\end{array}$ & $\begin{array}{l}\text { \$/kWh net } \\
\left(\$ / \mathrm{kg} \mathrm{H}_{2}\right) \\
\$ / \mathrm{gge} \text { at pump }\end{array}$ & $\begin{array}{c}6 \\
(200) \\
-*\end{array}$ & $\begin{array}{c}4 \\
(133) \\
2-3\end{array}$ \\
\hline
\end{tabular}

\footnotetext{
${ }^{2}$ http://www.hydrogen.energy.gov/annual_review07_proceedings.html ; note that gge equates to gasoline gallon equivalent

3 See the hydrogen storage section of DOE's Hydrogen, Fuel Cells \& Infrastructure Technologies Program's Multi-Year Research, Development and Demonstration Plan at http://www1.eere.energy.gov/hydrogenandfuelcells/mypp/pdfs/storage.pdf for a complete list of DOE's hydrogen storage technical targets.

${ }^{4}$ Another important goal is energy efficiency. For on-board reversible systems, greater than $90 \%$ energy efficiency for the energy delivered to the power plant from the on-board storage system is required. For systems regenerated off-board, the overall efficiency should be greater than $60 \%$ of the total energy input to the process.
} 
In addition to meeting the system capacity and cost targets, the Panel recognized that hydrogen storage systems must deliver hydrogen to the vehicle power plant efficiently. Particularly for systems with offboard regeneration, the overall efficiency is important. In this case, the energy content of the hydrogen delivered to the power plant should be greater than $60 \%$ of the total energy input to the process. This must include the input energy of hydrogen and any other fuel streams for generating process heat and electrical energy, as well as transportation of the fresh and spent fuel to and from the refueling station.

\section{Time Frame and Reporting Obligation}

The Panel conducted its evaluation from mid-May to mid-September of 2007, then prepared and submitted the final report and recommendation in accord with DOE's decision time line of FY 2007. In this report, the Panel documents the details of its deliberations, the results of its evaluation, and its unanimous recommendation. Appendix C (Table C-1) lists related documentation the Panel used in conducting this review.

\section{Recommendation and Conclusions}

The Panel unanimously decided to vote No-Go for the $\mathrm{NaBH}_{4}$-based, on-board hydrogen storage system for several reasons. First, based on the most convincing data presented by Millennium Cell and Rohm and Haas--coupled with the ANL and TIAX best-case analyses--the water-driven $\mathrm{NaBH}_{4}$ system cannot meet capacity performance targets for 2010. The Panel questioned whether the system could even meet any 2007 targets. Second, the memorandum the Panel received from the DOE's Chemical Hydrogen Storage Center of Excellence $(\mathrm{CoE})$ indicates that the $\mathrm{NaBH}_{4}$ approach is seen as being "highly risky" toward achieving the 2010 goals. This conclusion was largely based on the unproven volume-exchange tank design coupled with the substantial risk associated with achieving the 2010 cost targets, using any of the novel methods proposed. Third, most of the ideas for and approaches to improving capacity, efficiency, and regeneration being investigated have matured and have been optimized (at least in principle, if not in practice) to the point where they are as close to the targets as they are likely to get. Finally, the most promising regeneration concepts seem to be highly dependent on electric power and are coupled with optimistic expectations about what that power will cost.

Tables 2 and 3 (prepared by the Systems Integration Office) show how final FY 2007 results from Millennium Cell and Rohm and Haas presented at the September 2007 review compare with the stated DOE technical targets.

\section{Summary of On-Board Storage Reports}

Representatives of Millennium Cell, ANL and TIAX presented their reports at the September 2007 Panel review held at Argonne National Laboratory. Millennium Cell reported on the current state-of-the-art system for an on-board, $\mathrm{NaBH}_{4}$-based hydrogen generation system for an automobile. Such a system exists and has been used by DaimlerChrysler in an experimental car, the Natrium $^{5}$, as well as in a motorboat. The analysis is based on the hydrolysis of an aqueous $30 \%$ (this was not the case for the Natrium or motor boat) solution of $\mathrm{NaBH}_{4}$, containing 3\% sodium hydroxide $(\mathrm{NaOH})$ as a stabilizer. The hydrolysis is promoted by a proprietary catalyst. The $\mathrm{H}_{2}$ generation is controllable in an exothermic reaction, the sodium borohydride solution is nonflammable and stored at ambient temperature, and the $\mathrm{H}_{2}$ generated is pure (of sufficient purity for fuel cell operation). Factors that jeopardize the process include:

\footnotetext{
${ }^{5}$ Presentation by Tarek Abdel-Baset, Chryler LLC to Sodium Borohydride Go/No Go Decision Review Panel, July 2007.
} 
1) the unproven single-tank bladder system (which is based on a single-tank design separating fresh and spent fuel via a movable diaphragm), 2) the requirement for large amounts of water on board the vehicle, and 3) issues dealing with the precipitation of the sodium borate $\left(\mathrm{NaBO}_{2}\right)$ product. In addition, there are concerns about the practicality of using a $30 \%$ solution of $\mathrm{NaBH}_{4}$ at ambient temperature, which is near the solubility limit (and may be above it depending on temperature). ${ }^{6}$ Whether $\mathrm{NaBO}_{2}$ precipitation can be inhibited during the process of generating hydrogen is of concern, as is the problem of precipitation of the ultimate product of the reaction, solid sodium metaborate. Millennium Cell essentially concluded that the solution-based $\mathrm{NaBH}_{4}$ approach was not likely to achieve 2010 capacity targets. Millennium Cell also felt that the problem of accumulating a solid product was a significant engineering issue that had not been addressed adequately, and that no practical engineering solution has been proposed. Finally, Millennium Cell pointed out that the hydrogen cost remains above the target with this system.

Table 2. $\mathrm{NaBH}_{4}$ R\&D Results versus 2007 On-Board Storage Targets

\begin{tabular}{|c|c|c|c|c|c|c|c|}
\hline $\begin{array}{l}\text { Storage } \\
\text { Parameter }\end{array}$ & Units & $\begin{array}{c}2007 \\
\text { Target }\end{array}$ & $\begin{array}{l}\text { Millennium } \\
\text { Cell (based } \\
\text { on } 30 \text { wt \%) }\end{array}$ & $\begin{array}{c}\text { ANL } \\
\text { (based on } \\
24 \text { wt \%) }\end{array}$ & $\begin{array}{c}\text { ANL } \\
\text { (based on } \\
30 \mathrm{wt} \% \text { ) }\end{array}$ & $\begin{array}{c}\text { TIAX } \\
\text { (based on } \\
24 \text { wt \%) }\end{array}$ & $\begin{array}{c}\text { TIAX } \\
\text { (based on } \\
30 \text { wt \%) }\end{array}$ \\
\hline $\begin{array}{l}\text { System } \\
\text { gravimetric } \\
\text { capacity: Usable } \\
\text { specific energy } \\
\text { from } \mathrm{H}_{2} \text { (net } \\
\text { useful } \mathrm{H}_{2} / \text { max } \\
\text { system mass) }\end{array}$ & $\begin{array}{l}\mathrm{kWh} / \mathrm{kg} \\
(\mathrm{kg} \mathrm{H} / \mathrm{kg} \\
\text { system) }\end{array}$ & $\begin{array}{c}1.5 \\
(0.045)\end{array}$ & $1.5^{(a)(b)}$ & $\begin{array}{c}1.17 \\
(0.035)^{(\mathrm{b})}\end{array}$ & $\begin{array}{c}1.5 \\
(0.045)^{(a)(b)}\end{array}$ & $\begin{array}{c}1.1 \\
(0.033)^{(b)}\end{array}$ & $\frac{1.3}{(0.039)^{(a)(b)}}$ \\
\hline $\begin{array}{l}\text { System } \\
\text { volumetric } \\
\text { capacity: Usable } \\
\text { energy density } \\
\text { from } \mathrm{H}_{2} \text { (net } \\
\text { useful } \mathrm{H}_{2} / \mathrm{max} \\
\text { system volume) }\end{array}$ & $\begin{array}{l}\mathrm{kWh} / \mathrm{L} \\
\left(\mathrm{kg} \mathrm{H} \mathrm{H}_{2} / \mathrm{L}\right. \\
\text { system) }\end{array}$ & $\begin{array}{c}1.2 \\
(0.036)\end{array}$ & $1.22^{(a)(b)}$ & $\begin{array}{c}0.92 \\
(0.0276)^{(b)}\end{array}$ & $\begin{array}{c}1.21 \\
(0.0346)^{(a)(b)}\end{array}$ & $\begin{array}{c}0.87 \\
(0.026)^{(b)}\end{array}$ & $\frac{1.00}{(0.030)^{(a)(b)}}$ \\
\hline $\begin{array}{l}\text { Storage system } \\
\text { cost }\end{array}$ & $\begin{array}{l}\$ / \mathrm{kWh} \\
\text { net }(\$ / \mathrm{kg} \\
\left.\mathrm{H}_{2}\right)\end{array}$ & $\begin{array}{c}6 \\
(200)\end{array}$ & $6.7^{(\mathrm{c})}$ & $-^{(d)}$ & $-^{(d)}$ & $<5^{(\mathrm{c})}$ & $<5)^{(\mathrm{a})(\mathrm{c})}$ \\
\hline \multicolumn{8}{|c|}{ (a) Based on overly optimistic and unrealistic SBH concentration. } \\
\hline \multicolumn{8}{|c|}{$\begin{array}{l}\text { (b) The "net system" (i.e., "useable") capacities could be lower because of additional energy } \\
\text { requirements such as preventing precipitation. }\end{array}$} \\
\hline \multicolumn{8}{|c|}{ (c) The total cost will be higher because of the factors noted in (b) above. } \\
\hline \multicolumn{8}{|c|}{ (d) Indicates not calculated. } \\
\hline
\end{tabular}

\footnotetext{
${ }^{6}$ See Shang, Y.; and Chen, R. (2006). "Hydrogen Storage via the Hydrolysis of $\mathrm{NaBH}_{4}$ Basic Solution: Optimization of $\mathrm{NaBH}_{4}$ Concentration." Energy \& Fuels (20); pp. 2142-2148.
} 
Table 3. $\mathrm{NaBH}_{4}$ R\&D Results versus Hydrogen Cost Target and Regeneration Efficiency Goal

\begin{tabular}{|c|c|c|c|c|c|c|c|c|}
\hline \multirow[t]{2}{*}{$\begin{array}{l}\text { Storage } \\
\text { Parameter }\end{array}$} & \multirow[t]{2}{*}{ Units } & \multirow[t]{2}{*}{ Goal } & \multicolumn{3}{|c|}{ Millennium Cell Process } & \multicolumn{3}{|c|}{$\begin{array}{l}\text { Rohm and Haas Processes } \\
\text { A) Metal Reduction } \\
\text { B) Carbothermal }\end{array}$} \\
\hline & & & MCell & ANL & TIAX & $\mathrm{R} \& \mathrm{H}$ & ANL & TIAX \\
\hline $\begin{array}{l}\text { Regeneration } \\
\text { efficiency }\end{array}$ & $\%$ & 60 & $-^{(a)}$ & $\begin{array}{c}15.6- \\
21.3\end{array}$ & $-^{(a)}$ & $\begin{array}{l}\text { A) } 40^{(\mathrm{b})} \\
\text { B) } 50^{(\mathrm{b})}\end{array}$ & $12-17^{(b)}$ & $-^{(a)}$ \\
\hline $\begin{array}{l}\text { Hydrogen } \\
\underline{\text { cost }}\end{array}$ & $\begin{array}{l}\$ / g g e \\
\text { at } \\
\text { pump }\end{array}$ & $2-3$ & $9^{(c)}$ & $-^{(a)}$ & 10.33 & $\begin{array}{l}\text { A) } 10.70 \\
\text { B) } 6.00\end{array}$ & $-^{(a)}$ & $\begin{array}{l}\text { A) } 10.71 \\
\text { B) } 5.98\end{array}$ \\
\hline
\end{tabular}

The systems analyses reported to the Panel by ANL and TIAX were quite negative. ANL representatives suggested that a $30 \%$ solution of $\mathrm{NaBH}_{4}$ is an unrealistic specification and that $24 \%$ is a more appropriate concentration (but even then, precipitation of spent fuel remains a concern). With the more realistic $24 \%$ formulation, the 2007 target is not met. ANL also reported results showing that the on-board $\mathrm{NaBH}_{4}$ system might meet the 2007 storage capacity targets with the $30 \mathrm{wt} \%$ formulation, especially if the amount of $\mathrm{H}_{2}$ stored is $>8 \mathrm{~kg}$. However, ANL also indicated that capacities shown in Table 2 would not be met, if all technical issues raised were addressed. TIAX personnel reported that both the Millennium Cell design and the TIAX/ANL adjusted cases meet the DOE 2007 system cost target of $\$ 6 / \mathrm{kWh}$. However, the analysis did not account for the energy that will be required to prevent spent fuel precipitation, and therefore it is not confirmed that the 2007 target is met. There is, therefore, no clear pathway to meeting the 2010 or 2015 storage targets.

Independent of these issues of solution solubility and concentration, the clear consensus was that the 2010 technical targets cannot be met. ANL and TIAX personnel also raised concerns about the way total efficiency is defined. Some questions remain as to whether the total weight is correctly considered in the Millennium Cell analysis (e.g., the weight of the empty tank and the weight of the frame, among other factors). If such corrections were taken into consideration, the capacity values would have been even lower.

Almost all estimates of capacity by Millennium Cell, ANL, and TIAX were based on a single-tank (fuel/spent fuel) bladder system. Although this system would result in a significant enhancement in the volumetric density of the storage system over a dual-tank system (possibly approaching a factor of two), this design is an unproven technology, and would likely face significant implementation hurdles. Some of these hurdles include sealing, materials durability and compatibility resulting from high $\mathrm{pH}$, crystallization of the spent fuel, and heat management between the two compartments.

In addition, the Panel considered the fact that most of the quoted capacity numbers presented in the review were calculated estimates for proposed, but unproven, system designs. The Natrium system still represents the most compelling data for an actual, constructed system placed in a vehicle. But the capacity numbers for the Natrium system (quoted in the presentation by Tarek Abdel-Baset of Chrysler LLC, listed in Appendix C) are low, i.e., more than a factor of two below both the 2007 gravimetric and volumetric capacity targets. 


\section{Summary of Off-Board Regeneration Reports}

Representatives of Millennium Cell, Rohm and Haas, Pennsylvania State University (Penn State), ANL, and TIAX presented their results for off-board regeneration at the September 2007 review.

Millennium Cell reported that their approach was to improve the cost and efficiency of the $\mathrm{NaBH}_{4}$ Schlesinger Process by recycling sodium instead of resorting to alternative $\mathrm{NaBH}_{4}$ regeneration methods. Millennium Cell asserted that electrolysis of the sodium methoxide $\left(\mathrm{NaOCH}_{3}\right)$ formed in the $\mathrm{NaBH}_{4}$ synthesis step and of the sodium tetrahydroxy borate $\left[\mathrm{NaB}(\mathrm{OH})_{4}\right]$ product from the $\mathrm{H}_{2}$ formation step allows sodium to be recycled, thereby reducing the cost of $\mathrm{NaBH}_{4}$ by more than an order of magnitude. The electrolyses are more efficient than those described in previous work because membrane technology has been improved and because less corrosive methoxide is used instead of the more corrosive hydroxide. Although the raw materials are completely recycled, which substantially reduces energy costs, $\mathrm{NaBH}_{4}$ remains costly relative to goals for primary automotive fuel. Additionally, preliminary results presented on a "one-pot" synthesis suggest that with continued improvement, further cost reductions might be possible, bringing values in line with today's automotive fuel costs.

Penn State reported on efforts to electrochemically reduce $\mathrm{BO}_{2}^{-}$to $\mathrm{BH}_{4}^{-}$. The challenges of this eightelectron reduction process are significant but Penn State described some novel approaches. First, Penn State researchers have successfully demonstrated an analytical method that uses cyclic voltammetry to identify $\mathrm{BH}_{4}^{-}$. Efforts based on reduction in aqueous solution for $\mathrm{BO}_{2}^{-}$and in nonaqueous solutions for trimethoxyborohydride $\left[\mathrm{HB}\left(\mathrm{OCH}_{3}\right)_{3}\right]^{-}$yielded tentatively positive results (i.e., evidence that $\mathrm{BH}_{4}{ }^{-}$was formed), but that is the extent of the progress made. Penn State described some elegant experiments involving efforts to reduce electrostatic repulsion of the borate anion at the cathode, but again, this work is preliminary and inconclusive. And, although the Penn State work is interesting science, no progress has been made toward developing an electrochemical $\mathrm{NaBH}_{4}$ regeneration process. Based on the Penn State results, it seems highly unlikely that an aqueous-based electrochemical process is feasible for producing $\mathrm{NaBH}_{4}$ from borate in aqueous media.

The Rohm and Haas team reported at the outset of their presentation that $\mathrm{NaBH}_{4}$ options do not currently meet 2010 storage goals for hydrogen cost or energy efficiency. They did, however, describe new methods for regenerating $\mathrm{NaBH}_{4}$ using metals in the presence of $\mathrm{H}_{2}$ to reduce the hydrolysis product, $\mathrm{NaB}(\mathrm{OH})_{4}$. The team described two approaches. One involved a metal and $\mathrm{H}_{2}$ in a single-step process and the other involved formation of the metal hydride in a two-step process. In both cases, the metal hydride is the reducing agent. The researchers examined variations in conditions in milling processes and in other conditions where autoclave processes are used. The chemistry was successful in that $\mathrm{NaBH}_{4}$ was identified as the product and the cost of this fuel was reduced. The team's alternative approach, which uses a carbothermal reduction process, is less well developed but was shown to be successful in regenerating $\mathrm{NaBH}_{4}$ and reducing costs. Sensitivity analyses show that only in the most optimistic and unlikely case -- in which all aspects of overall process perform to the optimum and with the most favorable economic environment for syn gas -- could $\mathrm{NaBH}_{4}$ meet 2010 hydrogen cost targets. A key assumption here, along with several others discussed at length in the review, is whether electricity can realistically be expected to be available at $\$ 0.03 / \mathrm{kWh}$.

Analysis of the work by Rohm and Haas indicates significant potential hydrogen cost reduction for $\mathrm{NaBH}_{4}$ - a drop from approximately $\$ 200 /$ gge to about $\$ 10 /$ gge using the novel processes. Still, both Rohm and Haas processes fall short of the DOE targets. The efficiency for metal reduction is about $40 \%$ and the estimated gasoline gallon equivalent cost is about $\$ 10 /$ gge. For the carbothermal process, the efficiency is about $50 \%$ and the estimated gasoline gallon equivalent cost is about $\$ 6 /$ gge. 
The ANL and TIAX reports were uniformly unfavorable about the prognosis for success in achieving the DOE goals for 2010 via sodium borohydride. The ANL team reported that meeting the $60 \%$ regeneration efficiency goal is impossible if:

1) electricity demand in the regeneration process is $>18 \mathrm{kWh} / \mathrm{kg}-\mathrm{H}_{2}$ (note that the Millennium Cell process requires $>23 \mathrm{kWh} / \mathrm{kg}-\mathrm{H}_{2}$ ) for the processes analyzed, and

2) electricity comes from the projected 2015 U.S. grid mix.

The Millennium Cell process for recycling sodium is expensive in terms of electricity and hydrogen gas consumption. It is noted that Millennium Cell reported current efficiencies for their electrochemical process and ANL calculated overall regeneration efficiencies. ANL's calculation of regeneration efficiency for Millennium Cell's process lies in the range between $15 \%$ and $23 \%$ - much lower than the DOE goal of $60 \%$. ANL's researchers also stated that renewable options over a much longer time horizon could help meet the efficiency goal, provided the total amount of primary energy consumed in the fuel cycle is $<200 \mathrm{MJ} / \mathrm{kg}-\mathrm{H}_{2}\left(55.5 \mathrm{kWh} / \mathrm{kg} \mathrm{H}_{2}\right){ }^{7}$

TIAX representatives reported that

1) all the evaluated $\mathrm{NaBH}_{4}$ pathways are projected to cost more than the 2010 target of $\$ 2$ to $\$ 3 / \mathrm{kg}$ of hydrogen because of high regeneration costs;

2) the price of sodium is by far the most important cost driver for the sodium process;

3) no single cost driver could be identified that will significantly reduce the cost of the metal-reduction regeneration process, but energy supply is a major cross-cutting factor; and

4) the carbothermal process is not well enough developed to be accurately assessed.

There is no question that the reported cost and efficiency results for regeneration reported by both Millennium Cell and Rohm and Haas fall short of the DOE goals. The 2007 goals have not been achieved, making the prospect of achieving the 2010 and 2015 goals highly speculative. And even though the chemistry has shown much progress in the direction of meeting those targets, the prospects for going to the next level in meeting performance objectives are not promising. The Panel acknowledges that breakthrough advances in preparative chemistry are not easy, especially when dealing with methodology that has been in place for more than 50 years. Based purely on the criteria set out by DOE, the Panel's evaluation led to a No-Go decision.

However, the Panel recognizes that improvements in $\mathrm{NaBH}_{4}$ production have application to the cost-effective production of other borane-based species, for the amine borane on-board storage system, which is a major area of research under the DOE Chemical Hydride Center of Excellence. Note that this no-go decision on $\mathrm{NaBH}_{4}$ should not impact continued research activities for the cost-effective production of ammonia-borane and related systems.

\section{Additional Comments}

Clearly, a number of borane derivatives have high potential for hydrogen storage. The chemistry of the species, which include the tetrahydroborate salts, ammonia borane and some of its higher borane homologues, ammonium tetrahydroborate $\left(\mathrm{NH}_{4} \mathrm{BH}_{4}\right)$, and even some of the higher polyhedral boranes, has been well studied and appears to be a mature field. Of the hydroborates, hydrolysis of $\mathrm{NaBH}_{4}$ combines the best properties for storage and generation of $\mathrm{H}_{2}$, including solubility in water, rapid controllable hydrolysis, overall stability, and moderate exothermicity.

The chemistry of tetrahydroborates and the related amine boranes is well developed and is a major component of the global fine chemical industry. Boranes and hydroborates are major reagents in the drug

\footnotetext{
${ }^{7}$ ANL's well-to-tank efficiencies for the four sodium recycling options were based on the 2015 U.S. grid mix.
} 
and chemical industry. The formation of all of these materials relies on the single starting reagent, $\mathrm{NaBH}_{4}$. Schlesinger, Brown, and Finholt discovered a convenient synthesis of $\mathrm{NaBH}_{4}$ in the $1940 \mathrm{~s}$ and published their work when it was declassified in 1953. The method involves the reduction of trimethylborate by sodium hydride at $250^{\circ} \mathrm{C}$ in mineral oil. Because the process forms only 1 mole of $\mathrm{NaBH}_{4}$ per 4 moles of sodium, it is expensive. If this material were to be used as a source of on-board hydrogen in automobiles, alternative and less expensive means of production would be necessary.

Certainly, the hydrolysis of $\mathrm{NaBH}_{4}$ has some positive attributes. Millennium Cell has developed a system for on-board hydrogen generation that has been demonstrated in a concept vehicle (the DaimlerChrysler Natrium). Catalysts have been found to improve the $\mathrm{H}_{2}$ generation and extensive studies of the hydrolysis chamber have led to optimized performance. But considering the questions that remain about the use of a $30 \%$ solution of $\mathrm{NaBH}_{4}$ and about the problematic formation of solid $\mathrm{NaB}(\mathrm{OH})_{4}$, the Panel has concluded that these engineering problems have not been sufficiently addressed to inspire confidence that the system will actually work as proposed. Millennium Cell has also proposed methods for recycling sodium that would reduce the cost of $\mathrm{NaBH}_{4}$ by an order of magnitude. These include electrolysis of either $\mathrm{NaB}(\mathrm{OH})_{4}$ or $\mathrm{NaOCH}_{3}$ to sodium. More speculative preliminary experiments using lithium in a one-pot electrochemical synthesis of $\mathrm{MBH}_{4}$ (where $\mathrm{M}$ is a metal), have given good results via the intermediacy of the metal.

Rohm \& Haas provided the review panel with the results of a very professional and well-conceived approach to alternative routes to the regeneration of $\mathrm{NaBH}_{4}$ from borates. Their method utilizes reduction of $\mathrm{NaB}(\mathrm{OH})_{4}$ by metals other than Na. Many factors were considered in the selection of appropriate metals including cost and availability. Elegant chemistry was described involving either a direct method using metal and $\mathrm{H}_{2}$ or a two step process using metal hydride complexes. Alternative approaches involving carbothermal reduction based on an initial analysis, effectively employing methane to reduce the borate, has led to positive results. This work is in very much of a preliminary stage but has great potential.

The work done on novel regeneration pathways for $\mathrm{NaBH}_{4}$ by Millennium Cell and Rohm and Haas shows considerable progress, even though the goals for 2010 seem out of reach. On the other hand, improvements in $\mathrm{NaBH}_{4}$ production are very important to the whole DOE Chemical Hydrogen Storage $\mathrm{CoE}$ because $\mathrm{NaBH}_{4}$ is the key starting material for all the borane-based hydrogen storage materials. The Hydrogen Storage CoE might consider further work along these lines.

The efforts of the Penn State group certainly represent high-quality work, but the prognosis for satisfactory results for the eight-electron reduction process from $\mathrm{NaBO}_{2}$ to $\mathrm{NaBH}_{4}$ is not positive. Consequently, the case for continuing to fund this work must be made based on its value as fundamental long-term research rather than on the prospect of reaching the specific DOE goals. 


\section{Appendix A: Excerpt from Charter}

The Department of Energy (DOE) Hydrogen, Fuel Cells and Infrastructure Technologies Program has commissioned an Independent Review Panel to conduct a technical evaluation of the status and progress of research and development (R\&D) in the area of hydrolysis of sodium borohydride (SBH) for on-board vehicular hydrogen storage and its potential to meet the DOE's time-phased technical targets. This technical evaluation will be considered by DOE in making a Go/No-Go decision concerning the continuation of DOE-funded R\&D in this area.

\section{Methodology}

The primary source of information for the Panel's independent review will be briefings on current results provided by DOE contractors researching hydrolysis of SBH for on-board vehicular hydrogen storage as well as review of white papers and other technical documentation including those submitted in response to a Federal Register Announcement (see appendix B). The Panel may supplement this information by any or all of the following means: literature research, examination of project data and status reports, interviews with technical experts, visits to facilities, discussions with applicable organizations/individuals, attendance at program reviews, and formal presentations from interested parties.

\section{$\underline{\text { Evaluation Criteria }}$}

The Panel will base its hydrolysis of SBH Go/No-Go recommendation on an analysis of whether the following 2007 technical targets have been met:

(1) System Gravimetric Capacity: Usable, specific-energy from $\mathrm{H}_{2}$ (net useful energy/max system mass $)=1.5 \mathrm{kWh} / \mathrm{kg}\left(0.045 \mathrm{~kg} \mathrm{H}_{2} / \mathrm{kg}\right.$ system $)$

(2) System Volumetric Capacity: Usable energy density from $\mathrm{H}_{2}$ (net useful energy/max system volume $)=1.2 \mathrm{kWh} / \mathrm{L}\left(0.036 \mathrm{~kg} \mathrm{H}_{2} / \mathrm{L}\right.$ system $)$

(3) Storage system cost $=\$ 6 / \mathrm{kWh}$ net $\left(200 \$ / \mathrm{kg} \mathrm{H}_{2}\right)$

The Panel will also consider the likelihood that hydrolysis of SBH will meet the following 2010 technical targets:

(4) System Gravimetric Capacity: Usable, specific-energy from $\mathrm{H}_{2}$ (net useful energy/max system mass $)=2.0 \mathrm{kWh} / \mathrm{kg}(0.06 \mathrm{~kg} \mathrm{H} / \mathrm{kg}$ system $)$

(5) System Volumetric Capacity: Usable energy density from $\mathrm{H}_{2}$ (net useful energy/max system volume $)=1.5 \mathrm{kWh} / \mathrm{L}\left(0.045 \mathrm{~kg} \mathrm{H}_{2} / \mathrm{L}\right.$ system $)$

(6) Storage system cost $=\$ 4 / \mathrm{kWh}$ net $\left(133 \$ / \mathrm{kg} \mathrm{H}_{2}\right)$

(7) Fuel cost (spent fuel regeneration) $=\$ 2-3 /$ gal gas equivalent (gge) at pump.

In addition, hydrogen storage systems must be energy efficient in delivering hydrogen to the vehicle power plant. For on-board reversible systems, greater than $90 \%$ energy efficiency for the energy delivered to the power plant from the on-board storage system is required. For systems regenerated offboard, the overall efficiency is also important. In this case, the energy content of the hydrogen delivered to the automotive power plant should be greater than $60 \%$ of the total energy input to the process, including the input energy of hydrogen and any other fuel streams for generating process heat and electrical energy. (see http://www1.eere.energy.gov/hydrogenandfuelcells/mypp/pdfs/storage.pdf) 


\section{Appendix B: Federal Register Notice}

Federal Register Notice: December 20, 2006 (Volume 71, Number 244)

Notices

Page 76307-76308

From the Federal Register Online via GPO Access [wais.access.gpo.gov]

DOCID:fr20de06-62

DEPARTMENT OF ENERGY/Office of Energy Efficiency and Renewable Energy

Hydrolysis of Sodium Borohydride for On-Board Hydrogen Storage

Go/No-Go Decision

ACTION: Notice of request for technical input to go/no-go decision.

SUMMARY: The Department of Energy (the Department or DOE) Hydrogen, Fuel Cells and Infrastructure Technologies Program, is requesting position papers or other technical documentation regarding hydrolysis of sodium borohydride for on-board vehicular hydrogen storage applications by April 30, 2007. Information regarding regeneration of the spent fuel resulting from hydrolysis of sodium borohydride may also be submitted. This information will be used as part of DOE's go/no-go process in determining the future of DOE's program for applied research and development of hydrolysis of sodium borohydride for on-board hydrogen storage, including regeneration of the spent fuel.

DATES: Written position papers, articles or other technical documentation for consideration by the Department regarding this decision are welcome. Documents may be submitted via e-mail and must be received by April 30, 2007.

ADDRESSES: Please submit all documents to h2storage@go.doe.gov.

FOR FURTHER INFORMATION CONTACT: Grace Ordaz, U.S. Department of Energy, Office of Energy Efficiency and Renewable Energy, Mail Station

EE-2H, 1000 Independence Avenue, SW., Washington, DC 20585-0121, Phone:

(202) 586-8350, e-mail: grace.ordaz@ee.doe.gov.

SUPPLEMENTARY INFORMATION: The mission of the DOE's Hydrogen Program is to research, develop and validate fuel cell and hydrogen production, delivery, and storage technologies so that hydrogen from diverse domestic resources can be used in a clean, safe, reliable and affordable manner in fuel cell vehicles, electric power generation and combined heat and power applications. A critical requirement for enabling hydrogen fuel cell vehicles to achieve mass market penetration is the development of on-board hydrogen storage systems with enough capacity to meet driving range expectations (more than 300 miles in the United States), while meeting a number of requirements such as weight, volume and cost. Detailed technical targets developed by DOE, with input through the FreedomCAR and Fuel Partnership, are available at: http://www1.eere.energy.gov/hydrogenandfuelcells/mypp/pdfs/storage.pdf. 
To address the critical requirement of on-board hydrogen storage, the Program has established a "National Hydrogen Storage Project" including three Centers of Excellence and independent projects covering a diverse portfolio of hydrogen storage R\&D. Each Center of Excellence is focusing on a class of storage materials--metal (reversible) hydrides, chemical hydrides (non-reversible), and carbon (and other hydrogen adsorbent) materials. Each center has university, industry and national lab partners pursuing and leveraging their specific expertise in different areas. The Program has also expanded basic science efforts and coordination between DOE's Office of Energy Efficiency and Renewable Energy and Office of Science (see http://www.hydrogen.energy.gov).

On-board hydrogen storage systems must be developed that are safe, low cost and have high volumetric and gravimetric energy capacities in addition to meeting durability and operability requirements such as hydrogen charging and discharging rates. Periodic assessments and decision points on specific material technologies are included within the Hydrogen Storage sub-Program to meet the required targets within the Program timeframe. Within the current storage portfolio, a number of promising storage materials are being studied which have the potential for hydrogen storage capacities comparable to or greater than initially envisioned. In the material class of chemical hydrides, sodium borohydride has been shown to provide an adequate source of hydrogen upon hydrolysis of the material. However, since the hydrolysis reaction is not reversible on board the vehicle, processes for efficient off-board regeneration of the spent fuel, sodium borate, must be developed for the hydrolysis of sodium borohydride to be a viable on-board storage option. The DOE Hydrogen Program initiated research to develop efficient regeneration processes for sodium borohydride in 2003. Researchers supported by the DOE Program and other entities have made progress in improving the efficiency of there generation process over that of the current industrial process through which sodium borohydride is produced. However, the overall efficiency of the regeneration process remains low when compared to the DOE goal of $60 \%$. In 2005, DOE increased the level of effort for the efficient regeneration of spent fuel from hydrolysis of sodium borohydride by including this activity within the scope of DOE's Chemical Hydrogen Storage Center of Excellence. Results from these DOE R\&D activities will also be used in DOE's go/no-go process in determining the future of applied research and development of hydrolysis of sodium borohydride for on-board vehicular hydrogen storage and of regeneration processes for the spent fuel.

Scope of Decision Process: The DOE will make a decision regarding the future of its program for applied research and development of hydrolysis of sodium borohydride for on-board hydrogen storage by the end of September 2007. DOE will review the current state of activities related to hydrolysis of sodium borohydride, including the regeneration of spent fuel, and base its go/no-go decision on whether the following 2007 technical targets have been met:

(1) System Gravimetric Capacity: Usable, specific-energy from H2 (net useful energy/max system mass) $=1.5 \mathrm{kWh} / \mathrm{kg}$

(2) System Volumetric Capacity: Usable energy density from H2 (net useful energy/max system volume) $=1.2 \mathrm{kWh} / \mathrm{L}$

(3) Storage system cost $=\$ 6 / \mathrm{kWh}$ net

DOE will also consider the likelihood that sodium borohydride will meet the following 2010 technical targets:

(4) System Gravimetric Capacity: Usable, specific-energy from H2 (net useful energy/max system mass) $=2.0 \mathrm{kWh} / \mathrm{kg}$

(5) System Volumetric Capacity: Usable energy density from H2 (net useful energy/max system volume) $=1.5 \mathrm{kWh} / \mathrm{L}$

(6) Storage system cost $=\$ 4 / \mathrm{kWh}$ net

(7) Fuel cost (regeneration) $=\$ 2-3$ per gallon of gasoline equivalent at the pump. 
Position papers or other technical documents relevant to the go/no-go decision will be accepted by DOE for consideration in this decision. Position papers are limited to 10 pages maximum, and should contain a cover page with a point of contact, company name, address and email address. The cover page will not be counted in the 10 page limitation. Technical documents, such as published journal articles or preprints, are not restricted to the page limit. Position papers and other technical documents will be made available to the public and should not contain any proprietary information.

For more information about the DOE Hydrogen Program and related on-board hydrogen storage activities visit the Program's Web site at http://www.hydrogen.energy.gov and http://www.eere.energy.gov/hydrogenandfuelcells.

Issued in Golden, CO on December 12, 2006.

Jerry L. Zimmer,

Procurement Director, Golden Field Office.

[FR Doc. E6-21724 Filed 12-19-06; 8:45 am]

BILLING CODE 6450-01-P 


\section{Appendix C: Materials Reviewed by the Panel}

The Panel reviewed the materials listed in Table C-1 as part of its independent review.

Table C-1. Relevant $\mathrm{NaBH}_{4}$ Materials

\begin{tabular}{|c|c|c|c|c|}
\hline Laboratory/Company & Report Title & $\begin{array}{c}\text { Report } \\
\text { Date }\end{array}$ & Synopsis & Proprietary? \\
\hline \multirow[t]{4}{*}{$\begin{array}{l}\text { Argonne National } \\
\text { Laboratory }\end{array}$} & $\begin{array}{l}\mathrm{NaBH}_{4} \text { Regeneration Analysis- } \\
\text { Energy Requirements and } \\
\text { Efficiencies }\end{array}$ & $12 / 12 / 06$ & $\begin{array}{l}\text { Investigates energy requirements and } \\
\text { efficiencies for various } \mathrm{NaBH}_{4} \text { regeneration } \\
\text { options. }\end{array}$ & No \\
\hline & $\begin{array}{l}\text { Analysis of Sodium Borohydride On- } \\
\text { Board System }\end{array}$ & 09/10/07 & $\begin{array}{l}\text { Analyzes the Millennium Cell on-board } \mathrm{H}_{2} \\
\text { generation system and the treatment of the } \\
\text { spent } \mathrm{NaBO}_{2} \text {. }\end{array}$ & No \\
\hline & $\begin{array}{l}\text { Off-Board Regeneration of Sodium } \\
\text { Borohydride: Analysis of Electrolysis } \\
\text { Pathways with Sodium Recovery }\end{array}$ & 09/11/07 & $\begin{array}{l}\text { Analyzes the Millennium Cell efforts to recycle } \\
\text { sodium from electrolysis of } \mathrm{NaBO}_{2} \text {. }\end{array}$ & No \\
\hline & $\begin{array}{l}\text { Off-Board Regeneration of Sodium } \\
\text { Borohydride: Analysis of Pathways }\end{array}$ & 09/11/07 & $\begin{array}{l}\text { Analyzes the Rohm and Haas work on } \\
\text { regeneration of } \mathrm{NaBH}_{4} \text { by reducing } \mathrm{NaBO}_{2} \text { in } \\
\text { the presence of } \mathrm{H}_{2} \text {. }\end{array}$ & Yes \\
\hline \multirow[t]{3}{*}{ Millennium Cell } & $\begin{array}{l}\text { Review of Chemical Processes for the } \\
\text { Synthesis of Sodium Borohydride }\end{array}$ & $08 / 04$ & $\begin{array}{l}\text { Briefly reviews the } \mathrm{NaBH}_{4} \text { synthesis processes } \\
\text { that have been either reported in the literature } \\
\text { or studied in some detail by Millennium Cell. }\end{array}$ & No \\
\hline & $\begin{array}{l}\text { Quarterly Progress Report } \\
\text { Project Title: Development of an } \\
\text { Advanced Chemical Hydrogen } \\
\text { Storage and Generation } \\
\text { System }\end{array}$ & $01 / 31 / 07$ & Reports quarterly progress. & No \\
\hline & $\begin{array}{l}\text { Quarterly Progress Report } \\
\text { Project Title: Process for } \\
\text { Regeneration of Sodium Borate to } \\
\text { Sodium Borohydride for Use as a } \\
\text { Hydrogen Storage Source }\end{array}$ & $01 / 31 / 07$ & Reports quarterly progress. & No \\
\hline
\end{tabular}




\begin{tabular}{llcl}
\hline Laboratory/Company & Report Title & $\begin{array}{c}\text { Report } \\
\text { Date }\end{array}$ & Synopsis \\
\hline
\end{tabular}

Preliminary Draft: On-Board Fueling

System-Sodium Borohydride

Quarterly Progress Report

Project Title: Development of an

Advanced Chemical Hydrogen

Storage and Generation System

Quarterly Progress Report

Project Title: Process for

Regeneration of Sodium Borate to

Sodium Borohydride for Use as a

Hydrogen Storage Source

Process for the Regeneration of

Sodium Borate to Sodium

Borohydride

Development of an Advanced

Chemical Hydrogen Storage and

Generation System

Development of an Advanced

Chemical Hydrogen Storage and

Generation System

On-Board Fueling System Based on

Sodium Borohydride.

A Slide with Revised Estimates for the Go/No-Go Decision

Development of an Advanced

Chemical Hydrogen Storage and

Generation System
03/30/07

Describes the design of a fueling system based on $\mathrm{NaBH}_{4}$. This design is a much improved version from previous Millennium Cell designs.

04/30/07 Reports quarterly progress.

04/30/07 Reports quarterly progress.

05/16/07 Presented at 2007 Annual Merit Review.

05/16/07 Presented at 2007 Annual Merit Review.

No

07/13/07 Describes the final design of an on-board fueling system based on $\mathrm{NaBH}_{4}$

Presents Millennium Cell results with respect to storage targets.

09/10/07 Presents final on-board system design for the generation of $\mathrm{H}_{2}$.

o




\begin{tabular}{|c|c|c|c|c|}
\hline Laboratory/Company & Report Title & $\begin{array}{c}\text { Report } \\
\text { Date }\end{array}$ & Synopsis & Proprietary? \\
\hline & $\begin{array}{l}\text { Process for the Regeneration of } \\
\text { Sodium Borate to Sodium Metal }\end{array}$ & $09 / 11 / 07$ & $\begin{array}{l}\text { Presents final process for regenerating } \mathrm{NaBH}_{4} \\
\text { via the recycling of sodium. }\end{array}$ & No \\
\hline NREL & $\begin{array}{l}\text { Sodium Borohydride Teleconference } \\
\text { with Storage Tech Team }\end{array}$ & $06 / 21 / 07$ & $\begin{array}{l}\text { Captures discussions held during conference } \\
\text { call of June } 21 \text {. }\end{array}$ & No \\
\hline \multirow[t]{5}{*}{$\begin{array}{l}\text { Pennsylvania State } \\
\text { University }\end{array}$} & $\begin{array}{l}\text { Quarterly Progress Report } \\
\text { Project Title: DOE's Chem H CoE for } \\
\text { Chemical Hydrogen Storage: } \\
\text { Electrochemical Hydrogen Storage } \\
\text { Systems }\end{array}$ & $01 / 31 / 07$ & Reports quarterly progress. & No \\
\hline & $\begin{array}{l}\text { Quarterly Progress Report } \\
\text { Project Title: DOE's Chem H CoE for } \\
\text { Chemical Hydrogen Storage: } \\
\text { Electrochemical Hydrogen Storage } \\
\text { Systems }\end{array}$ & $04 / 30 / 07$ & Reports quarterly progress. & No \\
\hline & $\begin{array}{l}\text { Electrochemical Hydrogen Storage } \\
\text { Systems }\end{array}$ & $05 / 18 / 07$ & Presented at 2007 Annual Merit Review. & No \\
\hline & $\begin{array}{l}\text { Electrochemical Hydrogen Storage } \\
\text { Systems }\end{array}$ & 09/11/07 & $\begin{array}{l}\text { Presents final results of attempts to } \\
\text { electrochemically reduce } \mathrm{NaBO}_{2} \text { to } \mathrm{NaBH}_{4} \text {. }\end{array}$ & Yes \\
\hline & $\begin{array}{l}\text { Summary Report for DOE Go/No-Go } \\
\text { Meeting: Chemical Hydrogen Storage } \\
\text { Activities at PSU }\end{array}$ & No date & Summary of final review presentation & Yes \\
\hline \multirow[t]{2}{*}{ Rohm and Haas } & $\begin{array}{l}\text { Pathways to Sodium Borohydride: } \\
\text { A Literature Review }\end{array}$ & $01 / 07$ & $\begin{array}{l}\text { Reviews the technical and patent literature on } \\
\text { processes to manufacture borohydrides } \\
\text { (specifically } \mathrm{NaBH}_{4} \text { ) that have been proposed, } \\
\text { investigated, developed or commercialized. }\end{array}$ & No \\
\hline & $\begin{array}{l}\text { Quarterly Progress Report } \\
\text { Project Title: Novel Approaches to } \\
\text { Hydrogen Storage: Conversion of } \\
\text { Borates to Boron Hydrides }\end{array}$ & $01 / 31 / 07$ & Presents quarterly progress. & No \\
\hline
\end{tabular}




\begin{tabular}{|c|c|c|c|c|}
\hline Laboratory/Company & Report Title & $\begin{array}{l}\text { Report } \\
\text { Date }\end{array}$ & Synopsis & Proprietary? \\
\hline & $\begin{array}{l}\text { Milestone Report: } \\
\text { Sodium Borohydride Regeneration } \\
\text { Pathways }\end{array}$ & $02 / 16 / 07$ & $\begin{array}{l}\text { Analyzes the following milestone: Identify at } \\
\text { least one } \mathrm{NaBH}_{4} \text { regeneration process meeting } \\
\text { interim efficiency target of } 50 \% \text { for laboratory } \\
\text { demonstration and further development } \\
\text { studies. }\end{array}$ & Yes \\
\hline & $\begin{array}{l}\text { Quarterly Progress Report } \\
\text { Project Title: Novel Approaches to } \\
\text { Hydrogen Storage: Conversion of } \\
\text { Borates to Boron Hydrides }\end{array}$ & $04 / 30 / 07$ & Presents quarterly progress. & No \\
\hline & $\begin{array}{l}\text { Novel Approaches to Hydrogen } \\
\text { Storage: Conversion of Borates to } \\
\text { Boron Hydrides }\end{array}$ & $05 / 17 / 07$ & Presented at 2007 Annual Merit Review & No \\
\hline & $\begin{array}{l}\text { Cost Estimates of Novel Sodium } \\
\text { Borohydride Pathways }\end{array}$ & 08/01/07 & $\begin{array}{l}\text { Describes the preliminary evaluation of the } \\
\text { economics associated with two leading } \\
\text { regeneration pathways - metal reduction and } \\
\text { carbothermal reduction of } \mathrm{NaBO}_{2} \text { (3rd quarter } \\
2007 \text { milestone report). }\end{array}$ & Yes \\
\hline & $\mathrm{H} 2 \mathrm{~A} \mathrm{NaBH}{ }_{4}$ Regen.xls & $08 / 01 / 07$ & Presents results of $\mathrm{H} 2 \mathrm{~A}$ analysis. & $\begin{array}{l}\text { Yes } \\
\text { Yes }\end{array}$ \\
\hline & $\begin{array}{l}\text { DOE Review Panel Meeting for } \\
\text { Go/No-Go Decision on } \mathrm{NaBH}_{4} \\
\text { Hydrolysis for On-Board } \mathrm{H}_{2} \text { Storage. } \\
\text { Sodium Borohydride Regeneration }\end{array}$ & $09 / 11 / 07$ & $\begin{array}{l}\text { Reports on the work designed to regenerate } \\
\mathrm{NaBH}_{4} \text { from } \mathrm{NaBO}_{2} \text { using metal reduction and } \\
\text { a carbothermal process (final report). }\end{array}$ & \\
\hline \multirow[t]{2}{*}{ TIAX } & $\begin{array}{l}\text { IV.G.2 Cost Analysis of Hydrogen } \\
\text { Storage Systems }\end{array}$ & $\begin{array}{l}\text { FY } 2006 \\
\text { annual } \\
\text { progress } \\
\text { report }\end{array}$ & Summarizes 2006 on-board assessment work. & No \\
\hline & $\begin{array}{l}\text { Modeling of Advanced Storage } \\
\text { Options in the H2A Storage Options } \\
\text { in the H2A Framework (Part 2) }\end{array}$ & $\begin{array}{l}\text { 12/12/05 } \\
\text { (note: date } \\
\text { should } \\
\text { have been } \\
\text { 2006) }\end{array}$ & $\begin{array}{l}\text { Summarizes work in progress on the off-board } \\
\text { assessment for } \mathrm{NaBH}_{4} \text {. }\end{array}$ & No \\
\hline
\end{tabular}




\begin{tabular}{|c|c|c|c|c|}
\hline Laboratory/Company & Report Title & $\begin{array}{l}\text { Report } \\
\text { Date }\end{array}$ & Synopsis & Proprietary? \\
\hline & $\begin{array}{l}\text { Analyses of Hydrogen Storage } \\
\text { Materials and On-Board Systems }\end{array}$ & $09 / 10,11 / 07$ & $\begin{array}{l}\text { Assesses the Millennium Cell on-board } \mathrm{H}_{2} \\
\text { generation system and the Rohm and Haas off- } \\
\text { board regeneration systems. }\end{array}$ & Yes \\
\hline $\begin{array}{l}\text { Materials \& Energy } \\
\text { research Institute Tokyo } \\
\text { (MERIT), Ltd. }\end{array}$ & $\begin{array}{l}\text { Production \& Regeneration of Sodium } \\
\text { Borohydride from natural Resources }\end{array}$ & $\begin{array}{l}\text { Received } \\
4 / 10 / 07\end{array}$ & Response to Federal Register Notice & No \\
\hline $\begin{array}{l}\text { DOE Chemical } \\
\text { Hydrogen Storage } \\
\text { Center of Excellence }\end{array}$ & $\begin{array}{l}\text { Chemical Hydrogen Storage Center } \\
\text { of Excellence Input to DOE's Sodium } \\
\text { Borohydride Go/No-Go Decision }\end{array}$ & $8 / 30 / 07$ & $\begin{array}{l}\text { To outline what the CoE believes are the major } \\
\text { technical hurdles that still remain for SBH to } \\
\text { become a viable hydrogen storage option. }\end{array}$ & Yes \\
\hline \multirow[t]{5}{*}{ Other } & $\begin{array}{l}\text { Water and Heat Balance in a Fuel } \\
\text { Cell Vehicle with a Sodium } \\
\text { Borohydride Hydrogen Fuel } \\
\text { Processor }\end{array}$ & 2003 & $\begin{array}{l}\text { Discusses an NREL collaboration with } \\
\text { Millennium Cell and DaimlerChrysler to study } \\
\text { heat and water management in an } \mathrm{NaBH}_{4} \\
\text { storage/processor used to supply hydrogen to a } \\
\text { fuel cell in an automotive application. }\end{array}$ & No \\
\hline & $\begin{array}{l}\text { Assessment of Current State of } \\
\text { Technology for the Production of } \\
\text { Sodium Borohydride and Alternate } \\
\text { Hydrogen Storage Technologies }\end{array}$ & 09/16/03 & $\begin{array}{l}\text { Presents Bayer Technology Services' } \\
\text { evaluation of current technology in three areas: } \\
\text { (1) production of } \mathrm{NaBH}_{4} ;(2) \text { utilization of } \\
\mathrm{NaBH}_{4} \text { as a hydrogen storage system; and (3) } \\
\text { other hydrogen storage systems. }\end{array}$ & No \\
\hline & $\begin{array}{l}\text { Assessment of Sodium Borohydride } \\
\text { as an Alternative Hydrogen Storage } \\
\text { Technology }\end{array}$ & 07/04 & $\begin{array}{l}\text { Presented to FreedomCAR staff by Tarek } \\
\text { Abdel-Baset. }\end{array}$ & No \\
\hline & $\begin{array}{l}\text { Assessment of Sodium Borohydride } \\
\text { as an Alternative Hydrogen Storage } \\
\text { Technology }\end{array}$ & $06 / 21 / 07$ & $\begin{array}{l}\text { Presented to FreedomCAR staff by Tarek } \\
\text { Abdel-Baset. }\end{array}$ & No \\
\hline & $\begin{array}{l}\text { (Partial) List of Questions for } \\
\text { Millennium Cell Design of On-Board } \\
\text { Fueling System }\end{array}$ & No date & & No \\
\hline
\end{tabular}

